\title{
MICROCRYSTALLINE SILICON SOLAR CELLS AT HIGHER DEPOSITION RATES BY THE VHF-GD
}

\author{
P. TORRES, J. MEIER, M. GOETZ, N. BECK, U. KROLL, H. KEPPNER, AND A. SHAH \\ Institut de Microtechnique, Rue A.-L. Breguet 2, CH-2000 Neuchâtel, Switzerland
}

\begin{abstract}
A $7.7 \%$ single junction cell efficiency for an entirely microcrystalline silicon ( $\mu \mathrm{c}-\mathrm{Si}: \mathrm{H})$ device has recently been reported by our group [1]. This was achieved by applying the purifier technique, a technique which is indeed easier to handle than the earlier used "microdoping" approach. The purpose of the present paper is twofold: First to show in detail the impact on device performance when a gas purifier is used; and second to illustrate that the deposition rate of the active, absorbing i-layer can be increased from the former $1.55 \AA / \mathrm{s}$ up to $4.3 \AA / \mathrm{s}$ while still maintaining reasonable device performances. In the latter case a first n-i-p solar cell structure on an aluminium sheet could be fabricated with an efficiency of $4.9 \%$.
\end{abstract}

\section{INTRODUCTION}

As-grown undoped $\mu \mathrm{c}-\mathrm{Si}: \mathrm{H}$ has a strong n-type character which often hinders its application in devices. Two possible explanations for this non-intrinsic behaviour of undoped $\mu \mathrm{c}-\mathrm{Si}: \mathrm{H}$ have been given in the literature: structural native defects within the material or extrinsic oxygen impurities [2, 3]. Conceptually, both effects can be overcome by "microdoping", i.e. low-level boron doping. This method has been applied to standard GD [4], remote PECVD [3], reactive magnetron sputtering [5] and VHF-GD [6]. Outstanding early work by Veprek et al. [e.g. 7, 8,9] already showed the strong influence of incorporated oxygen impurities in $\mu \mathrm{c}-\mathrm{Si}: \mathrm{H}$; however, film growth was performed here by means of chemical transport in a hydrogen discharge: this specific deposition method may allow to grow relatively pure films and hence give the possibility to study fundamental aspects of the material, but it is definitely not suited for large-area applications as required for the deposition of photovoltaic devices. Indeed, the ultimate goal is to deposit "device-grade" $\mu \mathrm{c}-\mathrm{Si}: \mathrm{H}$ by means of a technique, as e. g. VHF-GD, with large-area capability.

The detrimental n-type character of undoped $\mu \mathrm{c}-\mathrm{Si}: \mathrm{H}$ is overcome in the work described in the present paper by the purifier technique $[10,11]$; thereby, the oxygen content in $\mu \mathrm{c}-\mathrm{Si}: \mathrm{H}$ can be reduced from the usual value of $10^{19}-10^{21}$ atoms $/ \mathrm{cm}^{3}$ down to $2.5 \times 10^{18}$ atoms $/ \mathrm{cm}^{3}$. This leads to "device-grade" $\mu \mathrm{c}-\mathrm{Si}: \mathrm{H}$ with a "midgap" character (Fermi level near the middle of the gap); consequently, "microdoping" can be omitted [12]. For comparison, note that in Czochralsky-grown silicon crystals, oxygen from the quartz crucible is generally present in concentrations of the order of $10^{18}$ atoms $/ \mathrm{cm}^{3}$ [13].

A second key issue addressed in this paper is to increase even further the deposition rates of the active, absorbing i-layer. This is a major concern, since $\mu \mathrm{c}-\mathrm{Si}: \mathrm{H}$ cells are about 10 times thicker than a-Si:H cells; note that this situation which applies to intrinsic $\mu \mathrm{c}-\mathrm{Si}: \mathrm{H}$ layers is in contrast with the situation prevailing for the very thin doped $\mu \mathrm{c}-\mathrm{Si}: \mathrm{H}$ layers that are used as contact layers in amorphous and other cells. In the present work deposition rates up to $4.3 \AA$ /s for 
"device-grade" $\mu \mathrm{c}-\mathrm{Si}: \mathrm{H}$ have been achieved and a first solar cell was fabricated with such a material.

\section{EXPERIMENTAL}

All layers and cells in this study were deposited in a single-chamber parallel-plate reactor by the VHF-GD technique. Doped contact layers were the same as those optimised in previous work $[14,15]$. The substrate is positioned upside down on the upper electrode, where the effective substrate temperature is kept at $170{ }^{\circ} \mathrm{C}-220^{\circ} \mathrm{C}$. The radio frequency is capacitively coupled to the lower electrode providing impedance matching for the entire frequency range of 55 to $200 \mathrm{MHz}$. The gases employed were silane $\left(\mathrm{SiH}_{4}\right)$, hydrogen $\left(\mathrm{H}_{2}\right)$, phosphine $\left(\mathrm{PH}_{3}\right)$ and diborane $\left(\mathrm{B}_{2} \mathrm{H}_{6}\right)$ diluted at $500 \mathrm{ppm}$ in $\mathrm{H}_{2}$. Gas pressure was kept in the range of $0.4-0.8 \mathrm{mbar}$ and the total gas flow was always $100 \mathrm{sccm}$. Dilutions are given in the following as $\%$ $\mathrm{SiH} 4 /$ total gas flow.

The approach followed for the purifying technique applied here, is to try to control all possible oxygen contamination sources: this implied both achieving a sufficiently low reactor outgasing rate of less than $1.5 \times 10^{-6}$ mbar $1 / \mathrm{sec}$ as well as using a gas purifier (the latter reduces the oxygen contamination down to the sub-ppb range in the feedgas). The combination of these two measures leads to a successful reduction of the oxygen content in a-Si:H as well as in $\mu \mathrm{c}-\mathrm{Si}: \mathrm{H}$ layers $[10,11]$.

Two p-i-n photovoltaic devices have been deposited, one with and one without applying the gas purifier to directly compare the effect on the active i-layer. The "standard" parameters employed here $(110 \mathrm{MHz}$ plasma excitation frequency, $6 \mathrm{~W}$ of applied rf-power, $2.5 \%$ dilution) result in $\mu \mathrm{c}-\mathrm{Si}: \mathrm{H}$ deposition rates of $1.55 \AA / \mathrm{s}$, as is typical for VHF-GD. This is already an order of magnitude higher when compared to deposition rates achieved by standard GD at $13.56 \mathrm{MHz}$ excitation frequency. Deposition is performed on glass coated with textured $\mathrm{SnO}_{2}$ (Asahi type $\mathrm{U}$ ). Back contacts for these "standard" cells are made of highly textured $\mathrm{ZnO}$ and $\mathrm{Ag}[16]$.

To increase the deposition rate, we even further increased the plasma excitation frequency to $130 \mathrm{MHz}$ and also increased the silane concentration to a dilution of 5\%. Two layers of a thickness of 2-3 $\mu \mathrm{m}$ were deposited on AF45 glass from Schott: one at a low rf-power of $7 \mathrm{~W}$ (at 0.4 mbar) and one at a high rf-power of $16 \mathrm{~W}$ (at $0.8 \mathrm{mbar}$ ), with deposition rates of 2.2 and $4.3 \AA / s$ respectively. The deposition pressure had thereby to be increased to keep the plasma confined between the electrodes. To determine the optical absorption of these layers, we performed photothermal deflection spectroscopy (PDS) and Transmission/Reflexion measurements.

The layer with the highest deposition rate $(130 \mathrm{MHz}, 16 \mathrm{~W})$ was thereafter implemented in a device: An inverted n-i-p photovoltaic cell was deposited on an Al sheet. The front contact was a merely sputtered ITO film, which optically performs quite well for a-Si:H based solar cells, but which is not an optimal antireflecting coating for $\mu \mathrm{c}-\mathrm{Si}: \mathrm{H}$ solar cells with their extended spectral response. This particular optical problem results in reduced short circuit current densities and is discussed elsewhere [17]. Back contacts are flat, sputtered $\mathrm{Ag}$ and $\mathrm{ZnO}$ to obtain a reflecting mirror. 


\section{RESULTS AND DISCUSSION}

Impact of the purifier technique on the solar cell performance

It is well known that the quality of the i-layer has a strong influence on the performance and, specifically, on the spectral response (SR) of a $\mu \mathrm{c}-\mathrm{Si}: \mathrm{H}$ solar cell device [18]. Fig. 1 shows the $\mathrm{SR}$ of an integral $\mu \mathrm{c}-\mathrm{Si}: \mathrm{H}$ p-i-n photovoltaic device ("standard" deposition parameters at $110 \mathrm{MHz}$, deposition rate of $1.55 \AA$ A/s) with the i-layers prepared with and without the feedgas purifier. The effect of reducing the oxygen content by means of using the gas purifier is remarkable and leads to a substantial increase in SR.

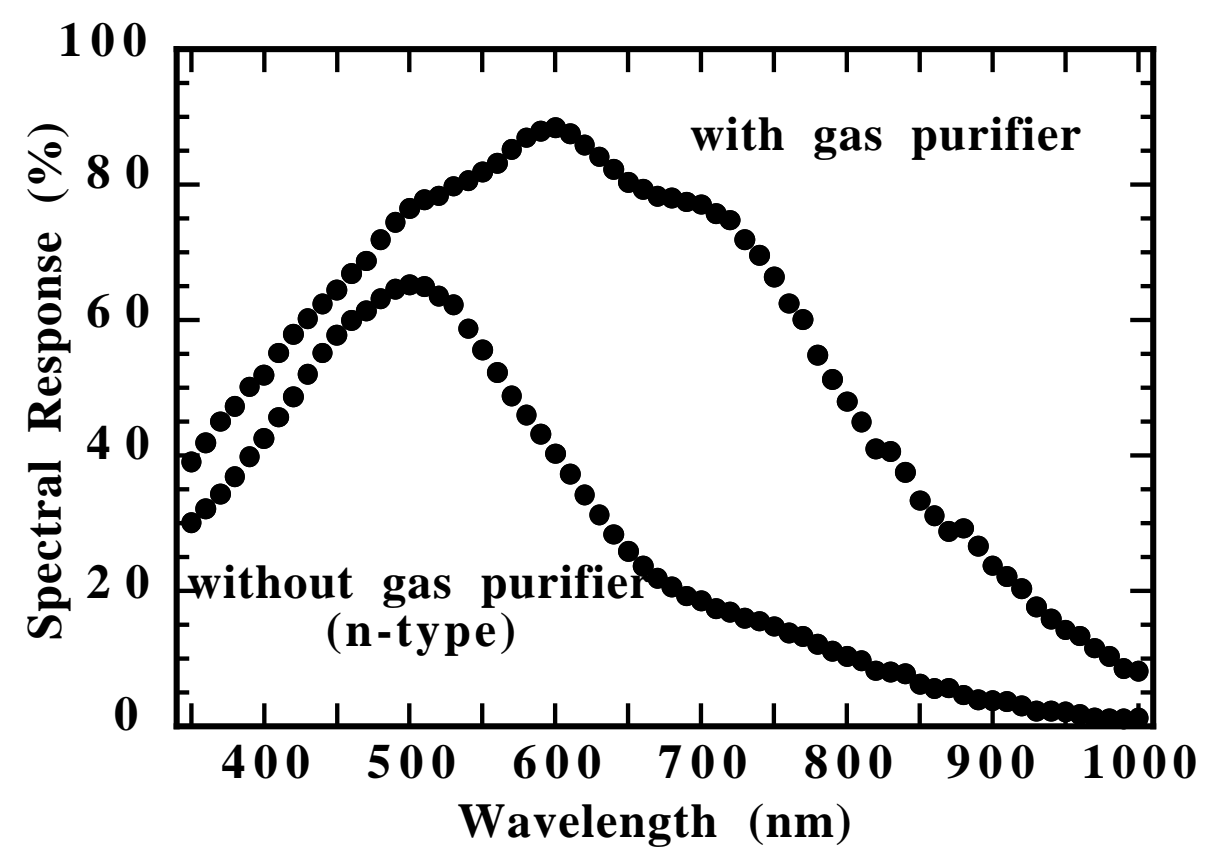

Fig. 1: Comparison of two $2.8 \mu \mathrm{m}$ thick $\mu \mathrm{c}-\mathrm{Si}: \mathrm{H}$ p-i-n solar cells. One was produced with and one without the feedgas purifier. "Standard" deposition conditions of $110 \mathrm{MHz}, 6 \mathrm{~W}$ result in a deposition rate of $1.55 \AA / s$ for both cells.

\begin{tabular}{|c|c|c|c|c|}
\hline degradation & Voc $(\mathrm{mV})$ & $\mathrm{Jsc}\left(\mathrm{mA} / \mathrm{cm}^{2}\right)$ & FF & eff. $(\%)$ \\
\hline before & 407 & 22.6 & 57.8 & 5.3 \\
\hline after & 418 & 22.4 & 57.2 & 5.3 \\
\hline
\end{tabular}

Table 1: Performance of the cell deposited with purifier (Fig. 1) before and after light soaking during $264 \mathrm{~h}$ at $50{ }^{\circ} \mathrm{C}$ with light from a high-pressure sodium lamp (light intensity equivalent to 8 sun).

For the cell shown here (deposited with the purifier technique) all photogenerated carriers are separated and collected at an i-layer thickness of $2.8 \mu \mathrm{m}$. Indeed, the SR measured at a bias tension of $-4 \mathrm{~V}$ remains, within measurement errors, identical to the one measured at $0 \mathrm{~V}$. Full characterisation under AM 1.5 conditions shows a cell efficiency of $5.3 \%$. Degradation experiments on this $\mu \mathrm{c}-\mathrm{Si}: \mathrm{H}$ solar cell support our earlier finding that $\mu \mathrm{c}-\mathrm{Si}: \mathrm{H}$ can be considered as a photovoltaically stable material: Exposure to light from a high-pressure sodium lamp at an intensity of about 8 suns, for a time period of $264 \mathrm{~h}$ and at a temperature of $50{ }^{\circ} \mathrm{C}$ did not show any light-induced degradation effect of this cell, as represented in Table 1. 
To get an answer to the question whether it is possible or not to further increase the deposition rates of $\mu \mathrm{c}-\mathrm{Si}: \mathrm{H}$ within the frame work of VHF-GD, several measures have simultaneously been applied: The silane concentration in the gas phase ratio was set to a dilution of 5\%, the rf-excitation frequency was increased to $130 \mathrm{MHz}$ and furthermore significantly higher plasma powers of up to $16 \mathrm{~W}$ were applied. Deposition rates increased thereby up to $4.3 \AA$ Aे/s. The gas purifier was used, here also, during deposition to avoid any additional ambiguity.

In Fig. 2 PDS absorption measurements are shown for two layers deposited under these new deposition conditions. It is surprising, that increasing the plasma power from 7 to $16 \mathrm{~W}$ does not lead to a higher defect density of the layer as evidenced by the low subbandgap absorption (Fig. 2), or to be more precise, any increase in the defect density of the layer - that may indeed be present - is not "seen" by PDS. 
The layer introduced above, which was grown at $130 \mathrm{MHz}$ and $16 \mathrm{~W}$, was thereafter implemented in a photovoltaic device to actually check its solar cell potential. The purifier technique was applied and a $3.85 \mu \mathrm{m}$ thick device was grown at a deposition rate of $4.3 \AA \mathrm{A} / \mathrm{s}$. The device was deposited in the $n-i-p$ configuration on an aluminium sheet. This option was chosen because such supporting substrates have many interesting application aspects, as e.g. omitting expensive textured TCO on glass as well as better potential for building integration [23]. Furthermore, the ductile Al sheet allows for a better stress relaxation. The spectral response (SR) of this device is shown in Fig.3 . Relatively high short circuit current densities of $23.89 \mathrm{~mA} / \mathrm{cm}^{2}$ could be achieved. This is surprising because a non-optimal front contact is used and no texturing is applied in this cell. Note that for comparison, usual p-i-n cells are deposited on highly textured TCO. Reverse biasing of the cell at -3V during SR results in an even higher Isc of $26.0 \mathrm{~mA} / \mathrm{cm}^{2}$. Full characterisation under AM 1.5 conditions shows a cell efficiency of $4.9 \%$ with a Voc of $382 \mathrm{mV}$ and a FF of $54 \%$. By integrating an identical device in a micromorph tandem structure $(\mu \mathrm{c}-\mathrm{Si}: \mathrm{H} / \mathrm{a}-\mathrm{Si}: \mathrm{H})$ a double-junction cell with $9.25 \%$ efficiency was obtained [17].

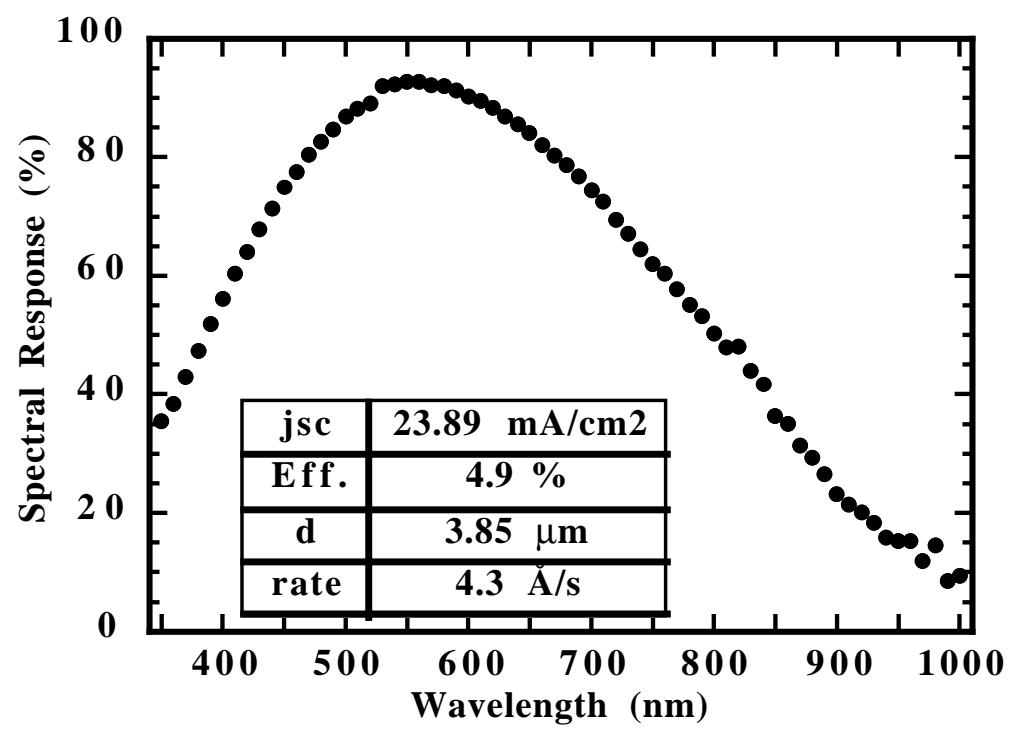

Fig. 3: $\mu c-S i: H$ n-i-p solar cell on aluminium sheet deposited at an increased deposition rate of $4.3 \AA / \mathrm{s}$. The back contact is flat sputtered $\mathrm{ZnO}$ and $\mathrm{Ag}$. The front contact is flat sputtered ITO which also acts as a single layer antireflecting coating.

\section{CONCLUSIONS AND OUTLOOK}

The purifier technique used in this work results in substantially enhanced device performance and even higher solar cell efficiencies than the earlier "microdoping" approach used by us and by other groups. Higher deposition rates up to $4.3 \AA$ As are reported here for the VHF-GD deposition method at a plasma excitation frequency of $130 \mathrm{MHz}$ and first experiments with such layers result in a single-junction cell efficiency of $4.9 \%$. Higher deposition rates as demonstrated in this paper may also be helpful in further reducing oxygen impurities in the layers.

However, not only the improvement of device performances but also the problem of deposition rates has to be further investigated in the future, in order to obtain entirely microcrystalline 
silicon solar cells that can be industrially relevant. The key issue is thereby not just to show that very fast deposition rates can be achieved for individual layers, but also to show that these very same layers actually perform efficiently in devices.

\section{ACKNOWLEDGEMENTS}

The technical assistance of S. Dubail is gratefully acknowledged. This work was supported by the Swiss Federal Office of Energy under Research Grant EF-REN (93) 032. We would like to thank Alusuisse Management Ltd. for supplying the aluminium substrates.

\section{REFERENCES}

[1] J. Meier, P. Torres, R. Platz, S. Dubail, U. Kroll, J.A. Anna Selvan, N. Pellaton Vaucher, Ch. Hof, D. Fischer, H. Keppner, A. Shah, K.-D. Ufert, P. Giannoulès, and J. Koehler, Mat. Res. Soc. Symposium, San Francisco (1996), to be published.

[2] C. Wang and G. Lucovsky, Proc. of 21st IEEE Spec. Conf., p. 1614, (1990).

[3] G. Lucovsky, C. Wang, M.J. Williams, Y.L. Chen, and D.M. Maher, Mat. Res. Soc. Symp. Proc. 283, 443 (1993).

[4] W. E. Spear, G. Willeke, and P. G. LeComber, Physica 117B \&118B, 908 (1983).

[5] W. A. Turner, M.J. Williams, Y.L .Chen, D.M. Maher, G. Lucovsky, Mat. Res. Soc. Symp. Proc. 283, 567 (1993).

[6] R. Flückiger, J. Meier, M. Götz, and A. Shah, J. Appl. Phys. 77, 712 (1995).

[7] S. Veprek, Z. Iqbal, R. O. Kühne, P. Capezzuto, F.-A. Sarott, and J. K. Gimzewski, J. Phys. C: Solid State Phys., 16, 6341 (1983).

[8] F. Mattenberger and S. Veprek, CHEMTRONICS, 1, 107 (1986).

[9] M. Konuma, H. Curtins, F.-A Sarott and S. Vepřek, Phil. Mag B, 55 - 3, 377 (1987).

[10] U. Kroll, J. Meier, H. Keppner, S.D. Littlewood, I.E. Kelly, P. Giannoulès, and A. Shah, Mat. Res. Soc. Symp. Proc. 377, 39 (1995).

[11] U. Kroll, J. Meier, H. Keppner, A. Shah, S.D. Littlewood, I.E. Kelly, and P. Giannoulès, J. Vac. Sci. Technol. A 13, 2724 (1995).

[12] P. Torres, J. Meier, R. Flückiger, U. Kroll, J. A. Anna Selvan, H. Keppner, A. Shah, S. D. Littlewood, I. E Kelly, and P. Giannoulès, Appl. Phys. Lett. 69, 1373 (1996).

[13] M.A. Green, High Efiiciency Silicon Solar Cells, Trans Tech Publications, ISBN 0-87849-537-1, 126 (Aedermannsdorf, 1987).

[14] K. Prasad, Ph. D. thesis, Institute of Microtechnology, University of Neuchâtel (1991).

[15] R. Flückiger, Ph. D. thesis, Institute of Microtechnology, University of Neuchâtel, ISBN 3-89191-965-4 (1995).

[16] J.A. Anna Selvan, H. Keppner, and A. Shah, Mat. Res. Soc. Symp., San Francisco (1996), to be published.

[17] M. Goetz, P. Torres, P. Pernet, Meier, D. Fischer, H. Keppner, and A. Shah, this conference.

[18] J. Meier, S. Dubail, R. Flückiger, D. Fischer, H. Keppner, and A. Shah, Proc. 24th IEEE, 409 (1994).

[19] M. A. Green, M. J. Keevers, Progress in Photovoltaics: Research and Applications 3, 189 (1995).

[20] N. Beck, P. Torres, J. Fric, Z. Remeš, A. Poruba, Ha Stuchlíková, A. Fejfar, N. Wyrsch, M. Vaněček, J.Kočka, A. Shah, this conference.

[21] N. Beck, J. Meier, J. Fric, Z. Remऍ̌s, A. Poruba, R. Flückiger, J. Pohl, A. Shah and M. Vaněček, J. Non-Cryst. Solids 198 - 200, 903 (1996).

[22] H. Keppner, U. Kroll, P. Torres, J. Meier, R. Platz, D. Fischer, N. Beck, S. Dubail, J.A. Anna Selvan, N. Pellaton Vaucher, M. Goerlitzer, Y. Ziegler, R. Tscharner, Ch. Hof, M. Goetz, P. Pernet, N. Wyrsch, J. Vuille, J. Cuperus, A. Shah, J. Pohl, and E. Bucher, this conference.

[23] M. Goetz, H. Keppner, P. Pernet, W. Hotz, and A. Shah, Mat. Res. Soc. San Francisco (1996), to be published. 